Opinião 


\section{Pesquisa básica versus pesquisa aplicada}

\section{OSWALDO UBRIAACO LOPES}

A questão da pesquisa básica versus pesquisa aplicada ou pesquisa A acadêmica versưs pesquisa tecnológica não é nova e certamente $\mathcal{L}$ náo se esgotará agora. Ela envolve o governo de uma naçáo, o dinheiro dos contribuintes e as prioridades que a administração no poder procura dar à sua atuação. A questão tem se repetido ciclicamente, de modo que os resultados começam a ser previsíveis.

Em 1966, coube ao presidente Lyndon Johnson disparar agudas farpas contra a ciência básica: "Presidents need to show more interest in what the specific results of research are - in their lifetime, and in their administration. A great deal of basic research has been done... but I think the time has come to zero in on the targets by trying to get our knowledge fully applied" (apud J. H. Conroe Jr., 1976).

O resultado para os Estados Unidos foi uma década relativamente pobre em avanços científicos e tecnológicos. Os norte-americanos carinhosamente costumam chamá-la de o tempo em que o foco de luz moveu-se do skylab para o backyard. Ela coincide, ou melhor, foi causada por uma média de investimentos de $2,2 \%$ do PIB/ano. Ela contrasta com um período extremamente florescente que foi o dos anos 60 (em média 2,8\% do PIB aplicados em P \& D), que alguns chamaram de efeito Sputnik, já que o lançamentơ do satélite soviético trouxe consigo uma forte competitividade, com investimentos altos em ciência básica e que não deixaram de ter retorno apreciável na parte aplicada. $\mathrm{Na}$ área da saúde contam-se, por exemplo, como retornos: produção de vacina de pólio, cirurgia com parada cardíaca, troca de válvulas cardíacas, hemodiálise renal, transplante renal, tratamenito da hipertensáo, etc.

Foi necessário outro desafio, no caso representado pelo Japáo e Alemanha, para que os Estados Unidos reconhecessem, ao que parece de modo definitivo, que liderança econômica e competitividade industrial estáo ligadas à pesquisa $\mathrm{e}$ ao desenvolvimento (retorno dos investimentos a patamares de $2,7 \%$ do PIB, na década de 80 ). A ciência básica é vital para a prosperidade, quer econômica quer social e deve ser cultivada não apenas pela glória do intelecto ou para manter a liderança no campo armamentista.

Aliás, na verdade, parece que, na questáo armamentista, a pesquisa 
básica pouco contribuiu. Conroe lembrou muito bem que o Project Hindsight, do Departamento de Defesa Americano (1966), ao analisar retrospectivamente vinte importantes armas militares, entre elas os mísseis Polaris e o Minutemann, o torpedo Mark 46 e as bombas nucleares múltiplas concluiu que: $1^{\circ}$ ) a contribuição das universidades foi mínima; $2^{\circ}$ ) os cientistas contribuíram mais efetivamente quando seu esforço foi do tipo objetivo definido; $3^{\circ}$ ) o tempo decorrido entre a descoberta inicial e a aplicação final era menor quando o cientista trabalhava em áreas demarcadas pelos seus financiadores. A conclusão é talvez maldosa, mas óbvia, a pesquisa dirigida é ótima para produzir armas e deve a todo custo evitar as universidades.

Em compensaçáo, quando o próprio Conroe (1976), com a ajuda de um excelente conjunto de consultores, analisou os dez maiores avanços em clínica e cirurgia cardiovascular e pulmonar dos últimos $\mathbf{3 0}$ anos, descobriu que, entre 529 trabalhos considerados essenciais ou cruciais para os avanços médicos naquelas áreas, $217(41 \%)$ eram primariamente básicos na sua origem, não estando seus autores, quando os realizaram, envolvidos em qualquer tipo de problema clínico, procurando na ocasião, como meta, apenas o conhecimento pelo conhecimento.

É inegável que, no mundo desenvolvido, a maior parte do dinheiro empregado em pesquisa e desenvolvimento terá a indústria como principal setor receptor do investimento, mas também é inegável que vem da própria indústria a maior parte do dinheiro nela empregado. Os valores dispendidos pela indústria podem chegar a $70 \%$ do total gasto em ciência e tecnologia, caso japonês, $60 \%$ na Alemanha e em torno de $50 \%$ para os Estados Unidos, França e Reino Unido.

Um exemplo pode ilustrar a questão. Não obstante tenham produtos internos incomensuravelmente diferentes, os governos de Japão e Brasil gastam aproximadamente o mesmo percentual, 0,6\% do PIB, em ciência e tecnologia. No caso brasileiro isso é praticamente tudo. No caso japonês, vem de outras fontes, sobretudo da indústria (70\%), o restante aplicado para inteirar os $2,8 \%$ do PIB destinados à ciência e à tecnologia. Os números americanos embutem o componente de armas e defesa e requerem um exame mais cuidadoso. Em 1987, por exemplo, $70 \%$ dos gastos governamentais americanos em pesquisa e desenvolvimento foram para objetivos tipo armas e defesa.

O governo brasileiro, num louvável esforço pela modernidade, propóe financiar a brecha tecnológica, procurando substituir a iniciativa privada, aparentemente nocauteada pelos custos financeiros, concordatas e recessáo à vista. $O$ problema é o de sempre, o modo de substituir, a dose. Há poucos, se os há, exemplos de sucesso em pesquisa dirigida. 
A ciência é árvore ranheta que só dá frutos solta no campo, muito manipulada, fenece. Se a universidade estiver plenamente atendida, se os institutos estiverem bem ou se irăo estar bem proximamente, então estaremos juntos no esforço de renovaçáo da política industrial. Os diabos são os ses...

Deveríamos, por fim, terminar lembrando que a questáo crucial que precisamos colocar talvez não seja a de ciência básica versus ciência aplicada, mas a de assegurar a transferência de tecnologia entre esses dois compartimentos mais do que de querer dimensioná-los.

CONROE, J. H. Jr. "Scientific Basis for the Support of Biomedical Science". Science 192: 105-111, 1976.

Oswaldo Ubriaco Lopes é professor do Departamento de Fisiologia do Instituto de Ciências Biomédicas da USP. Foi pró-reitor de Pós-Graduaçăo da USP. 